\title{
Analisis Prediksi Laju Korosi Pada SMAW Underwater Wet Welding Weldjoint Baja ASTM A36 karena Pengaruh Variasi Coating Elektroda dan Heat Input'
}

\author{
Arifin Amanto Putra, Herman Pratikno, dan Hasan Ikhwani \\ Departemen Teknik Kelautan, Fakultas Teknologi Kelautan, \\ Institut Teknologi Sepuluh Nopember (ITS) \\ e-mail: arifin7amanto@gmail.com
}

\begin{abstract}
Abstrak-Sejalan dengan berjalannya zaman, teknologi konstruksi bangunan laut berkembang sangat cepat dan sudah banyak variasi metode reparasi bangunan laut yang dapat menjadi alternatif. Tetapi perlu perhatian lebih pada metode reparasi yang digunakan agar reparasi tersebut menjadi maksimal. Oleh karena itu, penelitian ini bertujuan untuk mengetahui pengaruh variasi Coating Elektroda berupa pernis dan lilin serta heat input sebesar $1.0 \mathrm{~kJ} / \mathrm{mm}$ dan $1.3 \mathrm{~kJ} / \mathrm{mm}$ pada SMAW underwater wet welding baja ASTM A36. Pada prediksi laju korosi, nilai terendah didapatkan pada penggunaan coating elektroda lilin dan heat input $1.3 \mathrm{~kJ} / \mathrm{mm}$, yaitu $0.8 \mathrm{mmpy}$ dengan kategori wajar (Fair). Kemudian untuk nilai prediksi laju korosi pada variasi pengelasan lain masuk kedalam kategori buruk (poor). Seperti pada pengelasan dengan coating elektroda pernis dan heat input $1.3 \mathrm{~kJ} / \mathrm{mm}$ dan $1.0 \mathrm{~kJ} / \mathrm{mm}$ mempunyai nilai berturut-turut 2.60 mmpy dan $3.61 \mathrm{mmpy}$. Selain itu, pada pengelasan dengan coating elektroda lilin dengan heat input 1.0 $\mathrm{kJ} / \mathbf{m m}$ mempunyai nilai $1.22 \mathrm{mmpy}$ yang juga masuk ke dalam kategori buruk (poor). Selain prediksi laju korosi terdapat pengujian metalografi dan didapatkan presentase ferrite weld metal terendah terjadi pada pengelasan menggunakan coating elektroda lilin dan heat input $1.3 \mathrm{~kJ} / \mathrm{mm}$, yaitu $61 \%$. Maka, prediksi laju korosi yang didapatkan sebanding dengan presentase ferrite weld metal.
\end{abstract}

Kata Kunci - Underwater Wet Welding, Coating Elektroda, Heat Input

\section{PENDAHULUAN}

Seiring berkembangnya zaman, teknik pengelasan tidak hanya untuk memperbaiki benda atau struktur yang berada di udara terbuka namun juga dapat memperbaiki yang tercelup di dalam air laut. Pengelasan tersebut biasa disebut dengan underwater welding. Underwater welding telah banyak digunakan dalam perbaikan dan pemeliharaan konstruksi kelautan seperti pipa bawah laut, platform lepas pantai serta perangkat pelabuhan [1]. Secara umum diketahui bahwa pengelasan bawah air dapat diklasifikasikan menjadi dry welding dan wet welding. Dalam penelitian ini yang digunakan adalah metode pengelasan basah atau wet welding. Wet welding secara tradisional dilakukan dengan metode Shilded Metal Arc Welding (SMAW) [2].

Penggunaan pelindung elektroda pada underwater wet welding sangat penting. Seperti pada penelitian Menezes et. al. [3], mereka menggunakan elektroda konvensional yang dipernis dan elektroda yang diaglomerasi dengan polimer pada pengelasan basah bawah air di kedalaman 10 meter. Kemudian juga pada penilitian Das dan Jena [4] membandingkan elektroda tanpa pelindung dan pelindung berupa magnetit pada pengelasan di lingkungan laut.

Pada proses pengelasan, heat input adalah salah satu parameter yang penting dan berpengaruh pada hasil dan proses underwater wet welding. Banyak faktor yang bisa mempengaruhi nilai heat input, seperti arus, kecepatan pengelasan, dan voltase. Pada penelitian Li et.al. [5] menyatakan bahwa 6 variasi heat input memberikan efek yang berbeda pada stabilitas busur dan kualitas pengelasan pada underwater wet welding. Kemudian juga pada penelitian wang et. al. [6] menyatakan bahwa kecepatan pengelasan ternyata mempengaruhi gelembung dan stabilitas pengelasan pada underwater wet welding lembaran baja.

Pada penelitian ini, penulis ingin menganalisa pengaruh variasai coating elektroda dan heat input pada proses underwater wet welding. Jadi, penulis melakukan eksperimen pengelasan bawah air menggunakan pernis dan lilin sebagai coating elektroda and heat input $1.0 \mathrm{~kJ} / \mathrm{mm}$ dan $1.3 \mathrm{~kJ} / \mathrm{mm}$.

Untuk menguji kualitas yang dimiliki oleh sambungan las, maka penulis melakukan pengujian metalografi dan prediksi laju korosi. Seperti pada penelitian Sun [7] yang menyimpulkan bahwa ketahanan terhadap korosi lokal meningkat seiring dengan meningkatnya nilai heat input.

\section{METODOLOGI PENELITIAN}

\section{A. Pengelasan Basah Bawah Air SMAW}

Proses pengelasan ini berlangsung dalam keadaan basah dalam arti bahwa elektroda maupun benda berhubungan langsung dengan air. Aplikasi pengelasan sampai dengan kedalaman $150 \mathrm{~m}$. Metode pengelasan memberikan hasil yang kurang memuaskan, disamping memerlukan welder yang memiliki keahlian menyelam yang tangguh dan memerlukan pakaian khusus untuk selam, gelembung gas yang terjadi pada saat proses pengelasan akan sangat mengganggu pengamatan welder tersebut. Keuntungan dari metode SMAW wet welding yaitu biaya lebih murah dan pengoperasiannya lebih mudah. Sedangkan kekurangannya adalah terjadinya hydrogen embrittlement yang dapat menyebabkan crack dan microscophic failure pada struktur dan juga Poor visibility pada welder [8]. Proses SMAW dapat dilihat pada Gambar 1. 


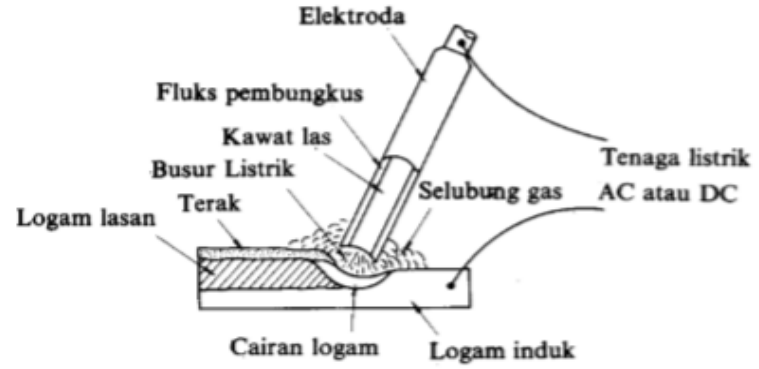

Gambar 1. Las Busur dengan Elektroda Terbungkus [9]

\section{B. Coating Elektroda}

Semua bagian harus sepenuhnya dilapisi, sehingga air tidak dapat berhubungan langsung dengan logam las. Coating Elektroda harus kedap air. Jika coating elektroda bocor, air akan bersentuhan dengan konduktor logam dan membuat busur tidak stabil. Selain itu, akan ada kerusakan cepat pada kabel tembaga. Dalam pengelasan bawah air, pernis dan lilin dapat digunakan sebagai pelapis elektroda.
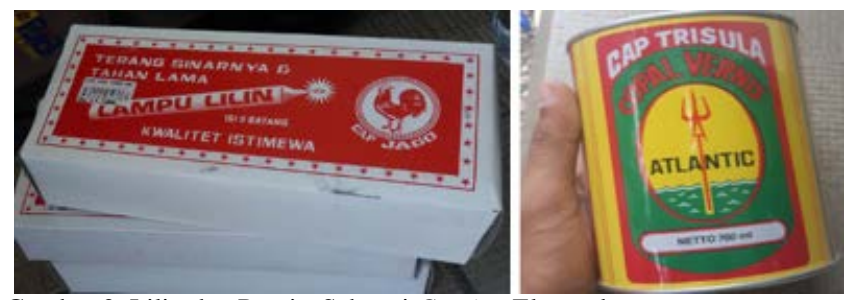

Gambar 2. Lilin dan Pernis Sebagai Coating Electroda

\section{Heat Input}

Heat input adalah nilai dari energi yang ditransfer per unit panjang dari suatu pengelasan. Heat input merupakan parameter penting karena heat input memperngaruhi laju pendinginan dan akan berpengaruh pada sifat mekanik dan struktur metalurgi dari HAZ. Rumus yang digunakan untuk menentukan besarnya heat input yaitu:

$$
H I=\frac{v \times I \times 60}{\text { Travel Speed }}
$$

dimana V adalah voltase busur las, dan I adalah arus.

\section{Prediksi Laju Korosi}

Prediksi laju korosi menggunakan metode sel 3 elektroda dan software NOVA untuk merekam arus yang dihasilkan pada setiap tegangan yang diberikan. Standar yang digunakan untuk melakukan pengujian ini adalah ASTM G48 [10]. Ukuran sampel yang digunakan untuk pengujian ini berukuran adalah $20 \mathrm{~mm}$ x $20 \mathrm{~mm}$ x $10 \mathrm{~mm}$ seperti pada Gambar 3.

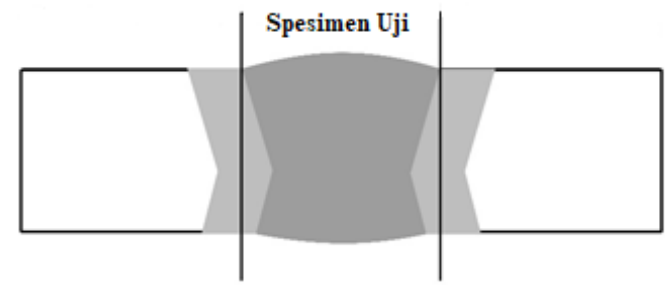

Gambar 3. Spesimen Uji Prediksi Laju Korosi

Metode elektrokimia ini menggunakan rumus yang didasari pada hukum Faraday sebagai berikut:

Dimana:

$$
\text { Laju Korosi }=\frac{k \times W}{A \times T \times D}=\frac{k \times a \times i}{n \times D}
$$

Laju korosi $=\mathrm{mm} /$ year atau mmpy

$$
\mathrm{K}=\underset{\text { Zmmpy) }}{\text { Konstanta (0.129 untuk mpy \& } 0.00327 \text { untuk }}
$$

$$
\begin{array}{ll}
\mathrm{T} & =\text { waktu }(\mathrm{Jam}) \\
\mathrm{A} & =\text { Luasan }(\mathrm{cm} 2) \\
\mathrm{W} & =\text { massa yang hilang }(\mathrm{gram}) \\
\mathrm{D} & =\text { massa jenis }(\mathrm{g} / \mathrm{cm} 3) \\
\mathrm{a} & =\text { berat atom logam yang terkorosi }(\mathrm{g} / \mathrm{mol}) \\
\mathrm{i} & =\text { ikor }=\text { kerapatn arus }(\mu \mathrm{A} / \mathrm{cm} 2) \\
\mathrm{n} & =\text { jumlah elektrin yang dilepas logam terkorosi. }
\end{array}
$$

Ketahanan terhadap korosi umumnya nilai laju korosi antara 1-200 mpy. Dapat dilihat pada tabel 2.5 di bawah ini yang menggolongkan tingkat ketahanan material berdasarkan laju korosinya. Pada tabel dapat diketahui tingkat ketahanan material mulai dari yang paling baik ketahanannya sampai yang jelek ketahanannya terhadap korosi.

Tabel 1.

Tingkat ketahanan Korosi Berdasarkan Laju Korosi [11]

\begin{tabular}{cccccc}
\hline \hline $\begin{array}{c}\text { Relative Corrosion } \\
\text { Resistance }\end{array}$ & $\mathrm{mpy}$ & $\mathrm{mm} / \mathrm{year}$ & $\mu \mathrm{m} / \mathrm{yr}$ & $\mathrm{Nm} / \mathrm{yr}$ & $\mathrm{pm} / \mathrm{yr}$ \\
\hline Outstanding & $<1$ & $<0.02$ & $<25$ & $<2$ & $<1$ \\
Excellent & $1-5$ & $0.02-0.1$ & $25-100$ & $2-10$ & $1-5$ \\
Good & $5-20$ & $0.1-0.5$ & $100-500$ & $10-50$ & $5-20$ \\
Fair & $20-50$ & $0.5-1$ & $500-1000$ & $50-100$ & $20-50$ \\
Poor & $50-200$ & $1-5$ & $1000-5000$ & $150-500$ & $50-200$ \\
Unacceptable & $200+$ & $5+$ & $5000+$ & $500+$ & $200+$ \\
\hline \hline
\end{tabular}

\section{E. Pengujian Metalografi}

Standar yang digunakan untuk pengujian metalografi adalah ASTM E3-01 "Standard Guide for Preparation of Metallographic Specimens" [12]. Foto makrostruktur diambil pada weld metal, HAZ, dan bse metal dengan pembesaran 7 kali. Sedangkan untuk foto mikro diambil menggunakan mikroskop elektron dengan perbesaran 100 kali pada base metal, HAZ, dan weld metal. Spesimen yang digunakan untuk pengujian metalografi sama dengan spesimen yang digunakan untuk uji kekerasan vickers, yaitu berukuran $60 \mathrm{x}$ 20 x $10 \mathrm{~mm}(6 \times 2 \times 1 \mathrm{~cm})$. Perhitungan persentase mikro menggunakan point counting method seperti yang ditunjukkan pada Gambar 4.

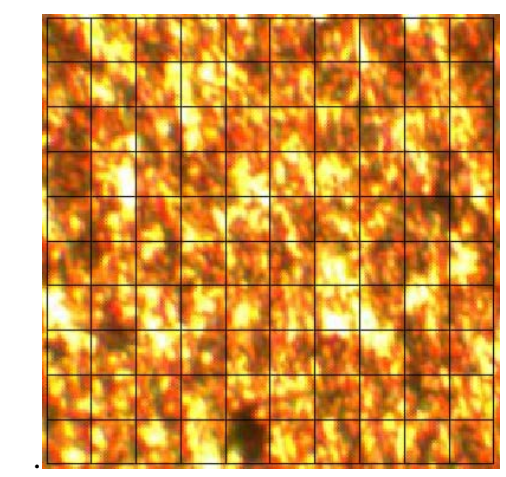

Gambar 4. Point Counting Method

\section{HASIL DAN DISKUSI}

\section{A. Prosedur Pengelasan}

Pada penelitian ini, SMAW underwater wet welding yang dilakukan menggunakan Welding Procedure Specification sebagai berikut:

- Spesifikasi Material : ASTM A36

- Dimensi : $300 \mathrm{~mm}$ x $150 \mathrm{~mm}$ x $10 \mathrm{~mm}$

- Tipe Sambungan : Butt Joint Single V-Groove

- Posisi Pengelasan : $1 \mathrm{G}$

- AWS No. (Class) : : AWS E 7016 
- Dia. Filler Metal

- Coating Electrode : Ø $2.6 \mathrm{~mm} \& \varnothing 3.2 \mathrm{~mm}$

- Arus

: Pernis dan lilin

- Jumlah Layer

: DCEP

- Metode Pembersihan : Griding \& Wire Brush

- Pada penggunaan heat input $1.3 \mathrm{~kJ} / \mathrm{mm}$, arus yang digunakan sebesar 75 ampere untuk layer pertama dan 100 ampere untuk layer kedua samapai keempat. Kemudian untuk voltase yang digunakan adalah 23 volts untuk semua layer.

- Pada penggunaan heat input $1.0 \mathrm{~kJ} / \mathrm{mm}$, arus yang digunakan sebesar 55 ampere untuk layer pertama dan 80 ampere untuk layer kedua samapai keempat. Kemudian untuk voltase yang digunakan adalah 22 volts untuk semua layer.

- Prosedur penelitian ini mengikuti penelitian Clukey [13]. Jadi penulis melapisi elektroda sejumlah 1 layer lilin dan pernis atau pencelupan satu kali pada sebuah wadah.

- Prose pengelasan dilakukan didalam sebuah bak dengan kedalaman air $5 \mathrm{~cm}$.

Gambar 5. Sambungan Las

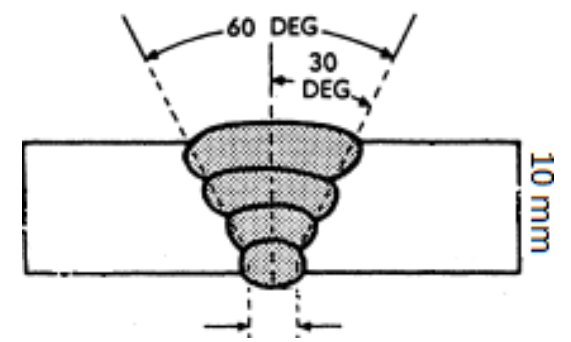

\section{B. Prediksi Laju Korosi}

Pada perhitungan prediksi laju korosi yang berdasarkan persamaan (1) menyatakan bahwa kerapatan arus (i $\mathrm{i}_{\text {corr }}$ ) berbanding lurus dengan nilai prediksi laju korosi yang nanti didapatkan. Semakin kecil nilai laju korosi suatu material, maka sifat ketahanan korosinya semakin baik [11]. Klasifikasi ketahanan korosi dalam dapat dilihat pada Tabel 1.

Tabel 2.

Hasil Prediksi Laju Korosi

\begin{tabular}{cccc}
\hline \hline Keterangan & $\begin{array}{c}\mathrm{E}_{\text {corr }} \\
(\mathrm{mV})\end{array}$ & $\begin{array}{c}\mathrm{i}_{\text {corr }} \\
\left(\mu \mathrm{A} / \mathrm{cm}^{2}\right)\end{array}$ & $\begin{array}{c}\text { Corrosion rate } \\
(\mathrm{mmpy})\end{array}$ \\
\hline $\begin{array}{c}\text { Coating Elektroda Pernis Heat Input } \\
1.3 \mathrm{~kJ} / \mathrm{mm}\end{array}$ & $-527,20$ & 223,66 & 2,60 \\
$\begin{array}{c}\text { Coating Elektroda Pernis Heat Input } \\
1.0 \mathrm{~kJ} / \mathrm{mm}\end{array}$ & $-603,12$ & 310,36 & 3,61 \\
$\begin{array}{c}\text { Coating Elektroda Lilin Heat Input } \\
1.3 \mathrm{~kJ} / \mathrm{mm}\end{array}$ & $-548,72$ & 69,02 & 0,80 \\
$\begin{array}{c}\text { Coating Elektroda Lilin Heat Input } \\
1.0 \mathrm{~kJ} / \mathrm{mm}\end{array}$ & $-528,75$ & 105,13 & 1,22 \\
\hline \hline
\end{tabular}

Dari hasil uji prediksi laju korosi pada Tabel 4.9, dapat disimpulkan bahwa nilai prediksi laju korosi yang paling rendah adalah pada pengelasan menggunakan coating elektroda lilin dan heat input $1.3 \mathrm{~kJ} / \mathrm{mm}$ yang mempunyai nilai 0.80 mmpy, dan dikategorikan baik (fair). Kemudian untuk nilai prediksi laju korosi pada variasi pengelasan lain masuk kedalam kategori buruk (poor). Seperti pada pengelasan dengan coating elektroda pernis dan heat input $1.3 \mathrm{~kJ} / \mathrm{mm}$ dan $1.0 \mathrm{~kJ} / \mathrm{mm}$ mempunyai nilai berturut-turut 2.60 mmpy dan 3.61 mmpy yang masuk dalam katerogi buruk (poor). Selain itu, pada pengelasan dengan coating elektroda lilin dengan heat input $1.0 \mathrm{~kJ} / \mathrm{mm}$ mempunyai nilai 1.22 mmpy yang juga masuk ke dalam kategori buruk (poor). Perlu diketahui bahwa kategori poor dihindari dalam dunia pengelasan SMAW underwater wet welding.

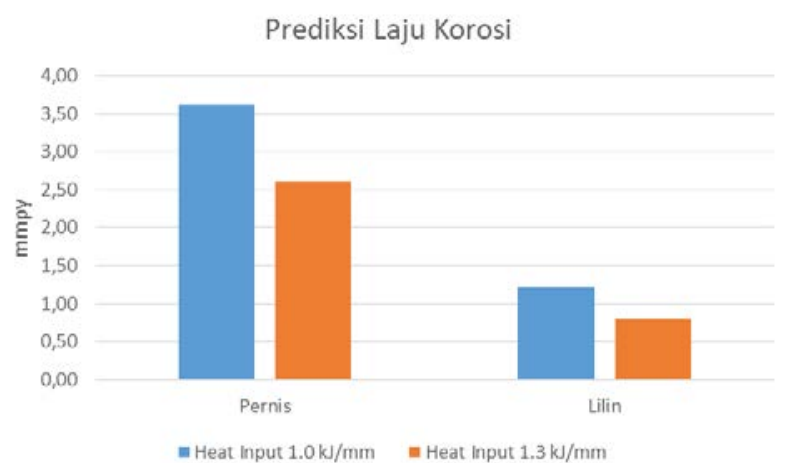

Gambar 6. Grafik Perbandingan Laju Korosi

Kemudian dari Gambar 6, dapat disimpulkan bahwa prediksi laju korosi pada penggunaan coating elektroda lilin mempunyai nilai yang lebih rendah jika dibandingkan dengan coating elektroda pernis. Hal ini dikarenakan lilin mudah terbakar saat proses pengelasan bawah air [13]. Sehingga material coating lilin akan terbakar bersamaan dengan logam las dan tidak menghalangi pandangan welder. Sedangkan pernis sifatnya lebih sulit terbakar dan membuat proses pengelesan menjadi kurang stabil. Material pernis yang terbakar pun menyebabkan lebih banyak kerak di las-lasan, gelembung gas lebih banyak dan air menjadi lebih keruh dan bias dibandingkan penggunaan lilin sebagai coating elektroda. Itulah yang membuat hasil lasan menggunakan coating elektroda pernis lebih buruk dibandingkan dengan pernis dan menghasilkan hasil prediksi laju korosi yang lebih buruk juga. Karakteristik serupa juga didapatkan pada penelitian Pranata [14] pada penggunaan coating elektroda sealent lebih sulit terbakar dibandingkan dengan lilin.

Lalu, dari hasil prediksi laju korosi juga didapatkan bahwa pengelasan bawah air dengan heat input yang lebih rendah akan menghasilkan nilai laju korosi yang lebih kecil. Hal ini dikarenakan nilai potensial $\left(E_{\text {corr }}\right)$ yang diperoleh cenderung menurun ketika heat input ditambah [15]. Hasil tersebut dapat dilihat dari nilai potensial ( $\left.\mathrm{E}_{\text {corr }}\right)$ yang didapatkan. Pada dasarnya, semakin negatif nilai potensial ( $\left.E_{\text {corr }}\right)$ logam, maka logam tersebut akan semakin bersifat reduktor kuat atau semakin mudah logam tersebut mengalami reaksi oksidasi. Sehingga, semakin mudah suatu logam mengalami reaksi oksidasi maka semakin mudah logam itu terkorosi. Nilai potensial $\left(E_{\text {corr }}\right)$ logam Hasil prediksi laju korosi pada penelitian ini dapat dilihat lengkapnya Gambar 7. Hasil penelitian ini juga didukung oleh pernyataan pada penelitian Sun et. al. [7] bahwa semakin tinggi heat input maka material akan semakin tahan terhadap korosi.
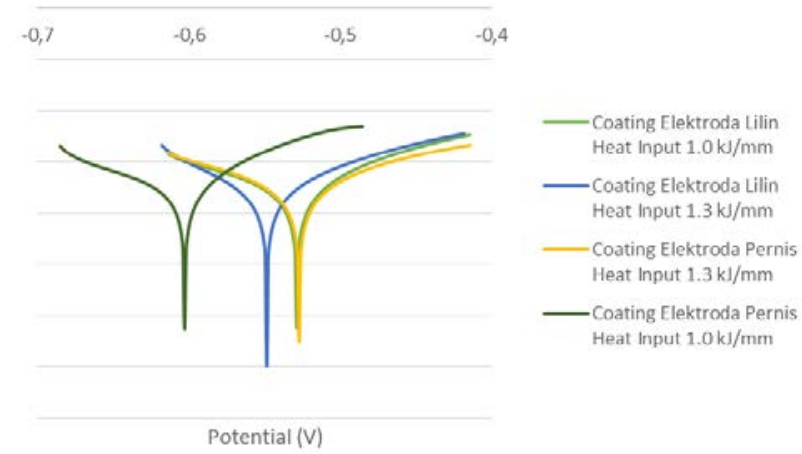

Gambar 7. Diagram Tafel Potensial Korosi 


\section{Pengujian Metalografi}

Pengujian metalografi terdiri dari foto struktur makro dan foto struktur mikro. Foto makro struktur menggunakan kamera DSLR dengan perbesaran 7x untuk melihat area base metal, HAZ, dan weld metal. Tujuan dari foto struktur makro adalah untuk mengukur lebar area HAZ dan untuk mengetahui cacat las secara makro. Sedangkan foto struktur mikro dilakukan pembesaran 100x dengan menggunakan mikroskop yang bertujuan untuk menghitung presentase bagian gelap (pearlite) dan bagian putih (ferrite) pada daerah base metal, dan weld metal serta presentase bagian gelap (pearlite), bagian putih (ferrite), dan transisi terang ke gelap (martensite) pada HAZ.
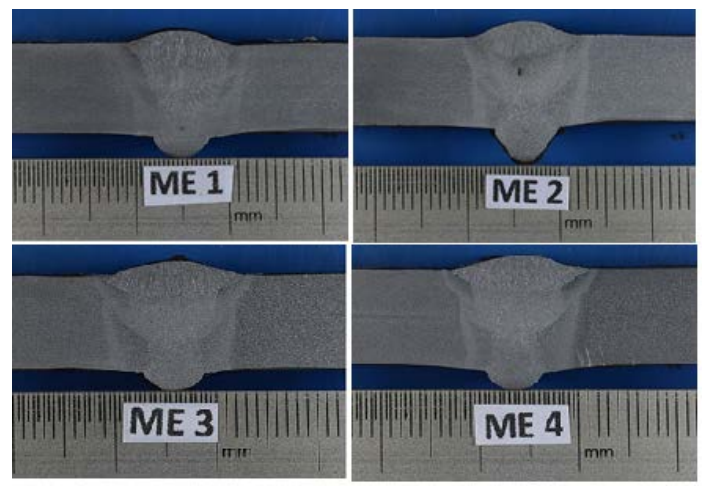

Gambar 8. Foto Struktur Makro

Pada foto struktur makro seperti pada Gambar 8, daerah HAZ terlebar didapatkan pada pengelasan menggunakan coating elektroda lilin dan heat input $1.3 \mathrm{~kJ} / \mathrm{mm}$, yaitu sebesar $1.58 \mathrm{~mm}$. Kemudian untuk pengelasan variasi lain dengan coating elektroda pernis dan heat input $1.3 \mathrm{~kJ} / \mathrm{mm}$, coating elektroda pernis dan heat input $1 \mathrm{~kJ} / \mathrm{mm}$, coating elektroda pernis dan heat input $1 \mathrm{~kJ} / \mathrm{mm}$, berturut-turut yaitu sebesar $1.51 \mathrm{~mm}, 1.41 \mathrm{~mm}$, dan $1.55 \mathrm{~mm}$.

Dari hasil tersebut, dapat disimpulkan bahwa jika heat input yang digunakan lebih besar, maka area HAZ akan lebih lebar. Hal tersebut dikarenakan jika nilai heat input yang digunakan lebih besar, maka butiran logam yang diperoleh dari elektroda akan lebih halus. Kemudian jika butiran logam lebih halus, maka akan lebih mudah memberikan gangguan panas yang signifikan pada daerah weld metal dan membuat daerah HAZ mendapatkan juga hasil yang lebih besar [16].

Kemudian, dari hasil tersebut juga didapatkan bahwa pengelasan menggunakan coating elektroda lilin memiliki area HAZ lebih lebar dibandingkan dengan menggunakan coating elektroda pernis. Hal tersebut dikarenakan lilin lebih mudah terbakar saat proses pengelasan bawah air [13]. Sehingga material coating lilin akan terbakar bersamaan dengan logam las dan membuat gangguan panas yang signifikan lebih mudah diberikan pada daerah weld metal. Jika weld metal mengalami gangguan panas yang signifikan, maka daerah HAZ mendapatkan juga terpengaruh dan menghasilkan area HAZ yang lebih lebar. Rekapitulasi lebar HAZ dalam bentuk grafik dapat dilihat pada Gambar 9.

Kemudian pada foto mikrostruktur, didapatkan bahwa semakin besar heat input yang diberikan maka berbanding lurus dengan penurunan komposisi ferrite dan kenaikan komposisi pearlite. Berdasarkan Diagram CCT (Continuous Cooling Transformation), Struktur mikro pada pengelasan terjadi karena adanya perubahan kecepatan pendinginan, yang berarti waktu pendinginan dari suhu austenit turun, struktur akhir yang terjadi berubah dari campuran feritpearlite ke campuran ferrite-perlite-bainite-martensite, ferite- bainite-martensite, kemudian bainite-martensite dan akhirnya pada kecepatan yang sangat tinggi maka struktur akhirnya adalah martensite.

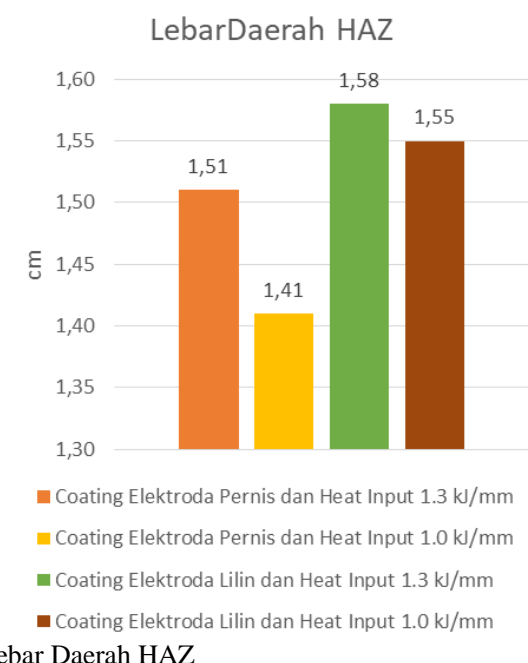

Gambar 9. Lebar Daerah HAZ

Dari Gabar 10, dapat dikatakan bahwa pengelasan bawah air akan membentuk fasa martensite pada daerah HAZ. Hal ini dapat terjadi karena pada daerah weld metal terjadi perubahan fasa dari austenite ke ferrite dan pearlite sedangkan pada daerah HAZ terjadi perubahan fasa austenite ke martensite. Pada perubahan fasa di daerah weld metal, hidrogen berpindah menuju daerah HAZ karena pada daerah weld metal fasa austenite tidak dapat menyerap hidrogen dan hidrogren terlarut dalam fasa ferrite [17].

Dari Tabel 3, dapat disimpulkan bahwa semakin besar heat input yang digunakan, maka komposisi ferrite weld metal akan semakin mengecil. Hal tersebut dikarenakan semakin besar heat input yang digunakan, maka kecepatan peleburan akan semakin cepat [5]. Jika kecepatan peleburan logam las semakin cepat, akan menyebabkan kecepatan pendinginan pada weld metal semakin cepat pula. Sehingga, material weld metal berdasarkan diagram CCT akan terbentuk ferrite yang lebih dominan. Dari komposisi ferrite yang dominan tersebut didapatkan karakteristik material yang diantaranya memiliki kekuatan tarik yang lebih kuat.

Kemudian, dari Tabel 3 juga dapat disimpulkan bahwa penggunaan coating elektroda lilin akan menghasilkan komposisi ferrite weld metal yang lebih kecil dibandingkan dengan penggunaan coating elektroda pernis. Hal tersebut dikarenakan lilin lebih mudah terbakar saat proses pengelasan bawah air [13]. Sehingga material coating lilin akan terbakar bersamaan dengan logam las dan coating elektroda pernis lebih sulit terbakar. Jika coating elektroda melebur semakin cepat, akan menyebabkan kecepatan pendinginan pada weld metal semakin cepat pula. Sehingga, material weld metal berdasarkan diagram CCT akan terbentuk ferrite yang lebih dominan. Dari komposisi ferrite yang dominan tersebut didapatkan karakteristik material yang diantaranya memiliki kekuatan tarik yang lebih kuat. 


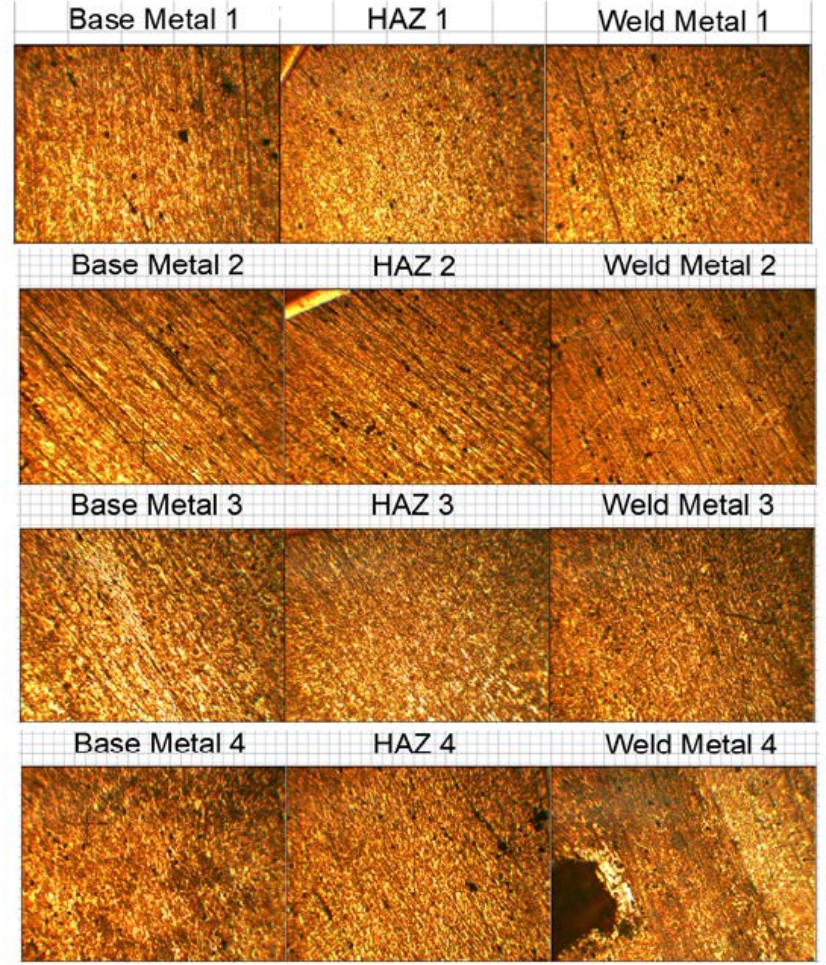

Gambar 10. Diagram Tafel Prediksi Laju Korosi

Tabel 3.

Hasil Mikrostruktur

\begin{tabular}{cccccccc}
\hline \hline \multirow{2}{*}{ No } & \multicolumn{2}{c}{ Base Metal } & \multicolumn{3}{c}{ HAZ } & \multicolumn{2}{c}{ Weld Metal } \\
\cline { 2 - 7 } & Pearlite & Ferrite & Pearlite & Martensite & Ferrite & Pearlite & Ferrite \\
\hline 1 & $29 \%$ & $71 \%$ & $25 \%$ & $23 \%$ & $52 \%$ & $30 \%$ & $70 \%$ \\
2 & $24 \%$ & $76 \%$ & $31 \%$ & $16 \%$ & $53 \%$ & $29 \%$ & $71 \%$ \\
3 & $37 \%$ & $63 \%$ & $34 \%$ & $25 \%$ & $41 \%$ & $39 \%$ & $61 \%$ \\
4 & $36 \%$ & $64 \%$ & $26 \%$ & $24 \%$ & $50 \%$ & $38 \%$ & $62 \%$ \\
\hline \hline
\end{tabular}

Dari hasil uraian diatas, maka didapatkan bahwa pengelasan dengan menggunakan coating elektroda lilin dan heat input $1.3 \mathrm{~kJ} / \mathrm{mm}$ dihasilkan presentase ferrite weld metal terkecil sebesar 61\%. Dengan hasil ini, maka disimpulkan pula pada pengelasan ini mempunyai kekuatan tarik yang paling kuat jika dibandingkan dengan pengelasan variasi yang lain.

Dari Gambar 11, kita bisa dapatkan urutan penurunan presentase ferrite pada base metal, HAZ, dan weld metal berturut-turut, yaitu pengelasan coating elektroda lilin dengan heat input $1.3 \mathrm{~kJ} / \mathrm{mm}$, pengelasan coating elektroda lilin dengan heat input $1.0 \mathrm{~kJ} / \mathrm{mm}$, pengelasan coating elektroda pernis dengan heat input $1.3 \mathrm{~kJ} / \mathrm{mm}$ dan pengelasan coating elektroda pernis dengan heat input $1.0 \mathrm{~kJ} / \mathrm{mm}$

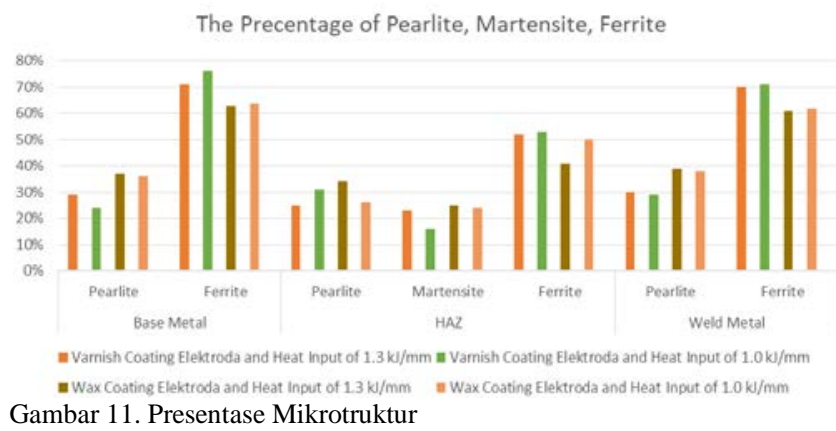

\section{Hubungan antara Prediksi Laju Korosi dan Metalografi}

Pada bagian ini, penulis ingin memaparkan hubungan dari pengujian yang telah dilakukan pada spesimen pengelasan SMAW di bawah air laut dengan variasi coating elektroda dan heat input. Nilai yang dibandingkan adalah perdiksi laju korosi, lebar HAZ dari foto makro, dan ferrite weld metal dari struktur mikro. Penjelasan lebih detail dapat dilihat pada Gambar 12, Gambar 13, Gambar 14, dan Gambar 15.

Pada Gambar 12 dan Gambar 13 merupakan hubungan antara prediksi laju korosi dan metalografi pada pengelasan mengguanakan pernis dan lilin sebagai coating elektroda. Dari gambar, dapat disimpulkan bahwa semakin besar heat input yang digunakan pada pengelasan basah bawah air dengan pernis dan lilin sebagai coating elektroda akan semakin kecil nilai prediksi laju korosi dan presentasi ferrite weld metal. Sedangkan lebar area HAZ memiliki grafik garis yang berbanding terbalik dari nilai prediksi laju korosi dan presentase ferrite weld metal. Hal tersebut dikarenakan jika heat input besar, maka butiran logam yang meleleh akan lebih halus. Kemudian jika butiran logam semakin halus, maka akan lebih mudah memberikan gangguan panas yang signifikan pada daerah weld metal dan membuat daerah HAZ mendapatkan juga hasil yang lebih besar [16]. Selain itu heat input yang semakin besar membuat kecepatan peleburan logam las semakin cepat [5]. Sehingga kecepatan pendinginan pada weld metal akan semakin cepat dan akan terbentuk ferrite yang lebih dominan. Lalu, meningkatnya heat input cenderung membuat nilai potensial $\left(\mathrm{E}_{\mathrm{corr}}\right)$ yang diperoleh [15]. Sehingga material semakin sulit mengalami reaksi oksidasi dan membuat prediksi laju korosi rendah.

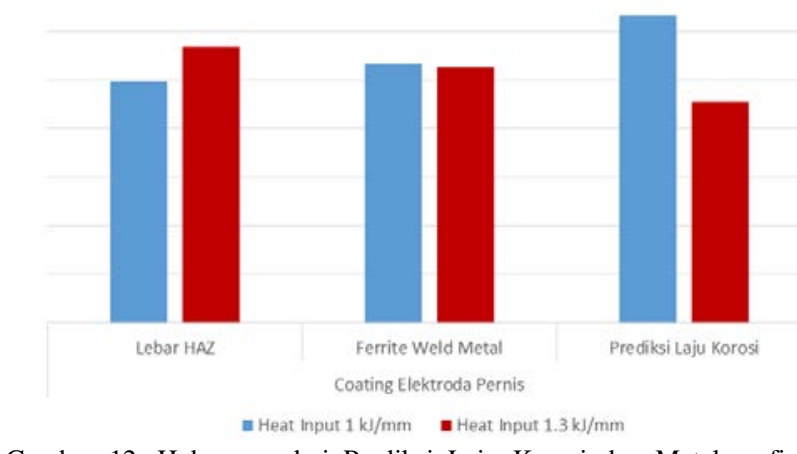

Gambar 12. Hubungan dari Prediksi Laju Korosi dan Metalografi pada Coating Elektroda Pernis

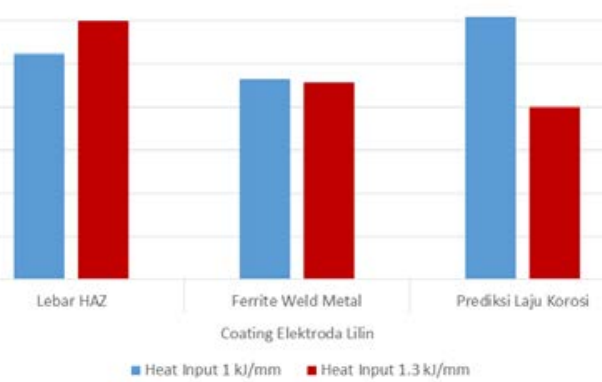

Gambar 13. Hubungan dari Prediksi Laju Korosi dan Metalografi pada Coating Elektroda Lilin

Kemudian pada Gambar 14 dan Gambar 15 merupakan hubungan antara prediksi laju korosi dan metalografi pada pengelasan dengan heat input $1.0 \mathrm{~kJ} / \mathrm{mm}$ dan $1.3 \mathrm{~kJ} / \mathrm{mm}$. Dari gambar, dapat disimpulkan bahwa pengelasan bawah air menggunakan coating elektroda lilin dengan heat input 1.0 $\mathrm{kJ} / \mathrm{mm}$ dan $1.3 \mathrm{~kJ} / \mathrm{mm}$ mengurangi nilai prediksi laju korosi dan presentasi ferrite weld metal dibandingkan dengan penggunaan coating elektroda pernis. Sedangkan lebar area HAZ memiliki grafik hasil yang berbanding terbalik dari nilai prediksi laju korosi dan presentase ferrite weld metal. Hal tersebut dikarenakan lilin mudah terbakar saat proses 
pengelasan bawah air [13]. Sehingga material lilin akan terbakar bersamaan dengan logam las dan tidak menghalangi pandangan welder. Sedangkan pernis sifatnya lebih sulit terbakar dan membuat proses pengelesan menjadi kurang stabil. Hal tersebut yang membuat hasil lasan menggunakan coating elektroda pernis lebih buruk jika dibandingkan dengan lilin, sehingga menghasilkan hasil prediksi laju korosi yang lebih tinggi. Selain itu, dikarenakan lilin lebih mudah terbakar dibandingkan pernis, maka kecepatan pendinginan akan semakin cepat pula. Sehingga membuat area HAZ melebar dan komposisi ferrite weld metal menurun. Karakteristik coating elektroda serupa juga didapatkan pada penelitian Pranata [14] pada penggunaan coating elektroda sealent yang lebih sulit terbakar dibandingkan dengan lilin.

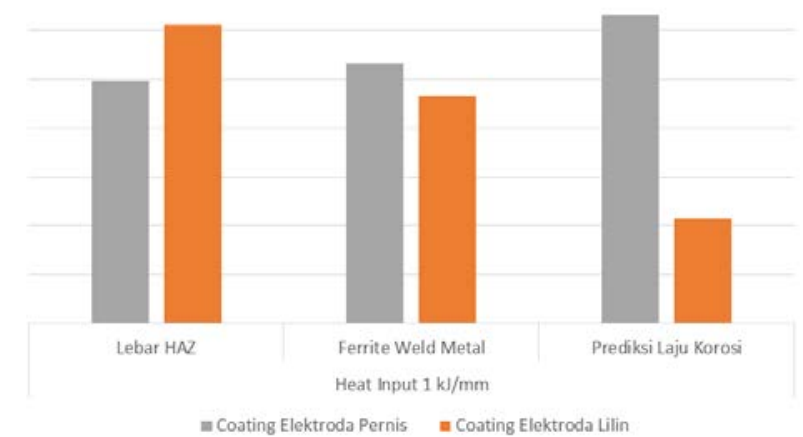

Gambar 14. Hubungan dari Prediksi Laju Korosi dan Metalografi pada Heat Input $1.0 \mathrm{~kJ} / \mathrm{mm}$

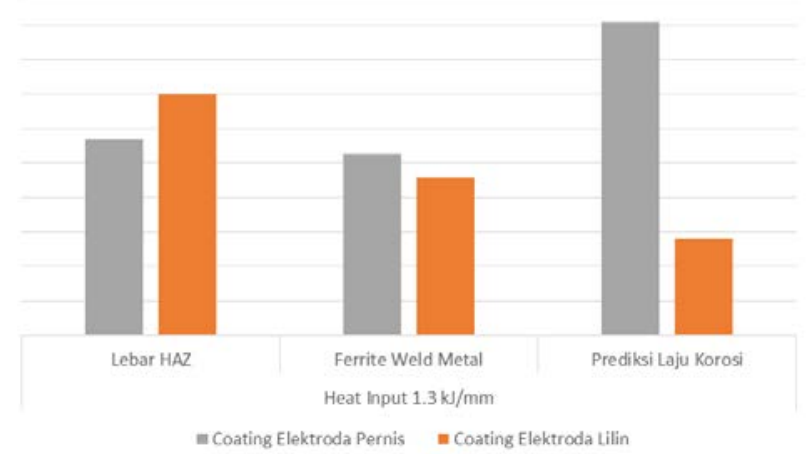

Gambar 15. Hubungan dari Prediksi Laju Korosi dan Metalografi pada Heat Input $1.3 \mathrm{~kJ} / \mathrm{mm}$

\section{KESIMPULAN DAN RINGKASAN}

Pada prediksi laju korosi, didapatkan pengelasan menggunakan coating elektroda lilin dan heat input 1.3 $\mathrm{kJ} / \mathrm{mm}$ memiliki nilai terendah, yaitu 0.80 mmpy dengan kategorikan baik (fair).

Pengelasan basah bawah air menggunakan coating elektroda lilin dan heat input $1.3 \mathrm{~kJ} / \mathrm{mm}$ memilki area HAZ terlebar pada foto makro sebesar $1.58 \mathrm{~cm}$ dan presentase ferrite weld metal terkecil sebesar $61 \%$ pada foto mikrostruktur.

Dari pengujian metalografi dan prediksi laju korosi, dapat disimpulkan bahwa nilai prediksi laju korosi dan presentase ferrite weld metal berbanding lurus. Sedangkan lebar HAZ dari foto makro yang didapatkan berbanding terbalik.

\section{DAFTAR PUSTAKA}

[1] H. Chen, Ning Guo, Xianghua Shi, Yongpeng Du, Jicai Feng, and Guodong Wang, "Effect of hydrostatic pressure on protective bubble characteristic and weld quality in underwater flux-cored wire wet welding,” Journal of Materials Processing Tech., 259, (2018) 159-168.
[2] G. Teran, R. Cuamatzi-Meléndeza, A. Albitera, C. Maldonadob, A.Q. Bracarensec, "Characterization of the mechanical properties and structural integrity of T-welded connections repaired by grinding and wet welding,” Material and Science Engineering Journal, 599, (2014) 105-115.

[3] P. H. R. Menezes, Ezequiel C. P. Pessoa and Alexandre Q. Bracarense, "Comparison of Underwater Wet Welding Performed with Silicate and Polymer Agglomerated Electrodes,” Journal of Materials Processing Technology, 259, (2018) 105-115.

[4] C. R. Das, and P. K. Jena, "A Study of Corrosion of Welded Steel Specimens in A marine Atmosphere, With And Without Protective Coatings,” Corrosion Science, 23, (1983) 1135-1140.

[5] H Li, Duo Liu, Yaotian Yan, Ning Guo, Yibo Liu, and JiCai Feng, "Effect of Heat Input on Arc Stability and Weld Quality in Underwater Wet Fluxed-cored Arc Welding of E40 Steel,” Journal of Manufacturing Processes, 31, (2018) 833-843.

[6] J. Wang, Qingjie Sun, Zuchen Pan, Jie Yang, dan Jicai Feng, "Effects of welding speed on bubble dynamics and process stability in mechanical constraint-assisted underwater wet welding of steel sheet," Journal of Materials Processing Technology, 259, (2018) 833-843.

[7] K. Sun, Ming Zeng, Yongsua Shi, Yu Hu, dan Xiaoqin Shen, "Microstructure and corrosion behavior of S32101 stainless steel underwater dry and wet welded joints, ” Journal of Materials Processing Technology, 256, (2018) 190-201.

[8] A. M. Joshi, "Underwater Welding," Bombay: Indian Institut of Technology (2002).

[9] H. Wiryosumarto, dan T. Okumura, Teknologi Pengelasan Logam, Jakarta: Pradnya Paramita (2008)

[10] ASTM G48-11, Standard Test Methods for Pitting and Crevice Corrosion Resistance of Stainless Steels and Related Alloys by Use of Ferric Chloride Solution, Washington: ASTM Publishing (2015)

[11]M. H. Fontana, Corrosion Engineering. New York: McGraw-Hill Book Company (1987).

[12]ASTM E3-01 Standard Guide for Preparation of Metallographic Speciments, Washington: ASTM Publishing (2002).

[13]D.A. Clukey, "Evaluation and Analysis of Underwater Wet Welding Processes,” Masterthesis, Columbus : The Ohio State University (1999)

[14]S.A. Pranata, "Analisa Perbandingan Laju Korosi Pada Pengelasan di Bawah Air Karena Pengaruh Variasi Jenis Pelindung Flux Elektroda,” Surabaya : ITS (2013)

[15]H. Pratikno, W. L. Dhanista, and A. F. Ramadhan, “Analysis Metallography and Corrosion Rate Prediction on ASTM A36 Steel From SMAW Underwater Welding," International Journal of Civil Engineering and Technology, 9, (2018) 1044-1052.

[16]A. R. Ramadhan, “Analisis Sifat Mekanis, Metallografi, dan Laju Korosi Pada Material Baja ASTM A36 Dari Hasil Pengelasan Bawah Air SMAW di Lingkungan Laut dengan Variasi Heat Input dan Elektroda,”Surabaya : ITS (2018)

[17] S. Kou, Welding Metallurgy, New Jersey: John Wiley \& Sons, Inc (2002) 